DOI: 10.12731/2658-6649-2019-11-5-2-62-67

УДК 612.017.1: 616.2

\title{
ОСОБЕННОСТИ НАЗАЛЬНОЙ МИКРОБИОТЫ ПРИ РЕСПИРАТОРНОЙ АТОПИИ И ПСЕВДОАТОПИИ В ЗАВИСИМОСТИ ОТ УРОВНЯ ПОРАЖЕНИЯ РЕСПИРАТОРНОГО ТРАКТА
}

\author{
Лазарева А.М., Коленчукова О.А., Смирнова С.В.
}

Приведена сравнительная характеристика назальной микробиоты при респираторной атопии и псевдоатопии в зависимости от уровня поражения респираторного тракта. В исследовании участвовали: истинньій атопический риносинусит (ИАР, $n=27)$, атопическая бронхиальная астма (БА, $n=27)$, полипозный риносинусит (ПРС, $n=67)$ и развернутая астматическая триада (РАT; $n=27)$. Контроль - здоровые доноры назальной микробиоты, от 19 до 63 лет, сопоставимые по полу и возрасту с больныли. Микрофлора слизистой оболочки носа выращена на питательных дифференциально-диагностических средах. Выделяя генез поражения дыхательных путей, для риносинуситов определена высокая концентращия представителей рода Enterobacteriaceae при ИАР относительно ПРС, для нижних дыхательных путей - высокая кониентрация рода Enterococcus в группе БА относительно РАТ. Суммарное количество микробиоты выше при атопии (АР и БА) относительно контроля.

Ключевые слова: микробиота; атопический риносинусит; атопическая бронхиальная астма; астматическая триада; полипозньй риносинусит.

\section{FEATURES OF NASAL MICROBIOTA IN PATIENTS WITH RESPIRATORY ATOPY AND PSEUDOATOPY DEPENDING ON THE LEVEL OF INJURY OF RESPIRATORY TRACT}

\section{Lazareva A.M., Kolenchukova O.A., Smirnova S.V.}

Comparative characteristic of the nasal microbiota in respiratory atopy and pseudoatropy depending on the level of the lesion respiratory tract. The 
study involved: true atopic rhinosinusitis (IAR, $n=27)$, atopic bronchial asthma $(B A, n=27)$, polypous rhinosinusitis (PRS, $n=67)$ and deployed asthmatic triad (RAT; $n=27)$. Control - healthy nasal microbiota donors, from 19 to 63 years, comparable in sex and age with patients. Microbiota with the mucosa grown on differential diagnostic media. Highlighting the genesis and level of damage to the respiratory tract in allergies, rhinosinusitis determined a high concentration of representatives of the genus Enterobacteriaceae in IAR relative to PRS. For the lower respiratory tract, a high concentration of Enterococcus genus in the BA group relative to RAT was established. The total amount of microbiota is higher in atopic inflammation of the respiratory tract (AR and $B A$ ) relative to the control.

Keywords: microbiota; atopic rhinosinusitis; atopic asthma; polypous rhinosinusitis; asthmatic triad.

\section{Введение}

Риносинусит и бронхиальная астма - это классические проявления респираторной аллергии. Они тесно взаимосвязаны, это обусловлено схожестью механизмов воспаления и единством генетического фона.

Чаще всего, в их основе лежат атопические механизмы. Однако существуют и неиммунологические (псевдоатопические) механизмы с появлением клинической фенокопии риносинусита и бронхиальной астмы. Классический пример - полипозный риносинусит (ПРС) и аспириновая астма. Аспириновая астма входит в состав развернутой астматической триады (РАТ) - ПРС, непереносимость ненаркотических и нестероидных противовоспалительных препаратов, бронхиальная астма. Бронхиальная астма часто развивается после оперативного лечения ПРС. Таким образом, ПРС можно рассматривать как манифестацию РАТ.

Микробный пейзаж слизистой оболочки носа играет важное значение в инициации аллергического воспаления [1]. Девиации микробиоты могут быть как самостоятельными, запуская компенсаторные реакции иммунной системы, так и вторичными - следствием вторичного иммунодефицита [2]. Таким образом, возможно предотвратить запуск иммунного воспаления, выявив предикторы развития патологии с учетом уровня и генеза аллергии респираторного тракта [3].

\section{Материалы и методы}

Обследованы больные истинным атопическим риносинуситом (ИАР, $\mathrm{n}=27$ ), бронхиальной астмой (БА, $\mathrm{n}=27$ ), полипозным риносинуситом 
(ПРС, $\mathrm{n}=67)$, развернутой астматической триадой (РАТ, $\mathrm{n}=27)$, в возрасте от 19 до 63 лет. Группа контроля - здоровые доноры назальной микробиоты (n=207), сопоставимые по полу и возрасту с больными. Диагностика проводилась оториноларингологом с аллергологом-иммунологом в период обострения. Взятие биоматериала со слизистой оболочки носа проводили стерильными тумферами с коммерческой средой Эймса. Посев осуществляли методом секторов на питательные дифференциально-диагностические среды (КА, ЖСА, Эндо, энтерококк-агар). Инкубация в термостате при $37^{\circ} \mathrm{C}$ в течение суток.

Право на проведение обследования юридически подтверждено информированным согласием пациента. Протокол обследования соответствовал этическим стандартам и был принят комитетом по биомедицинской этике НИИ МПС.

Для статистического анализа использовали пакет прикладных программ Statistica 7.0. Выборка описана с подсчетом медианы и интерквартильного размаха в виде 25 и 75 перцентилей. Достоверность различий оценивали по непараметрическому критерию Манна-Уитни. Критический уровень значимости равен 0,05 .

\section{Результаты}

Изучена микробиота слизистой оболочки носа при риносинуситах и бронхиальной астме различного генеза. Нормальное количество микрофлоры, не требующей коррекции - это $10^{3} \mathrm{KOЕ/мл.} \mathrm{Изучение} \mathrm{микро-}$ флоры слизистой при ПРС, ИАР, РАТ и БА обнаружило доминирование микроорганизмов рода Staphylococcus $(\mathrm{P}<0,001 ; \mathrm{P}=0,05 ; \mathrm{P}<0,001 ; \mathrm{P}<0,001)$ и Streptococcus ( $\mathrm{P}<0,001 ; \mathrm{P}=0,03 ; \mathrm{P}<0,001 ; \mathrm{P}<0,001$, соответственно). Концентрация Enterobacteriaceae выше при ПРС, ИАР и БА $(\mathrm{P}<0,001$; $\mathrm{P}=0,02 ; \mathrm{P}<0,001)$ относительно контроля. При ИАР, РАТ и БА количество Enterococcus выше $10^{3}$ ( $\left.\mathrm{P}<0,001\right)$, при ПРС и в группе контроля данный микроорганизм не обнаружен. При этом, при БА его концентрация достоверно выше относительно РАТ (Р $<0,001)$.

Исследование состава микробиоты при различном генезе риносинуситов обнаружило увеличение КОЕ/мл семейства Enterobacteriaceae при ИАР относительно ПРС ( $<0,001)$. Для групп бронхиальной астмы (независимо от генеза) установлено высокое содержание рода Enterococcus при БА относительно РАТ (Р<0,001). Видовой состава микрофлоры слизистой при ПРС отличался высокой концентрацией Streptococcus pneumoniae $(\mathrm{P}=0,012)$ относительно контроля. 
При ИАР концентрация условно-патогенных микроорганизмов находилась в пределах нормы, за исключением Haemophilus influenzae, его количество было статистически значимо выше, чем в контроле $(\mathrm{P}<0,001)$. При этом, в группе ИАР на слизистой обнаружены такие бактерии как Streptococcus haemolyticus, Enterococcus faecium, Enterococcus faecalis, которых нет в контрольной группе $(\mathrm{P}<0,001)$. В группе ПРС отсутствуют некоторые представители условно-патогенной микрофлоры (Enterococcus, Haemophilus influenzae).

Изучение видовой принадлежности рода Staphylococcus, выявило увеличение общей численности штаммов S. aureus, относящихся к коагулазопозитивным стафилококкам в группе ИАР $(\mathrm{P}<0,001)$. При этом, частота выявления и концентрация коагулазонегативных стафилококков также выше, чем в группе контроля. Выявлено большое видовое разнообразие микроорганизмов рода Staphylococcus: S.epidermidis $(\mathrm{P}<0,001)$, S.haemolyticus $(\mathrm{P}=0,039)$, S.hominis $(\mathrm{P}<0,001)$, S.cohnii $(\mathrm{P}<0,001)$, S.capitis $(\mathrm{P}<0,001)$, S.hyicius $(\mathrm{P}<0,001)$. Интересен факт выявления на слизистой таких стафилококков как S.aureus, S.epidermidis, S.haemolyticus, S.hominis, S.cohnii, S.capitis, S.hyicius при ИАР, в группе ПРС - S.aureus, S.epidermidis, S.haemolyticus, S.hominis, S.capiti. В контрольной группе штаммов таких видов как S.capitis и S.hyicius не обнаружено.

Содержание штамма Staphylococcus hominis при ПРС выше относительно ИАР (P=0,029). В целом, в группе ПРС состав микроорганизмов рода Staphylococcus, был значительно беднее по сравнению с группой ИАР.

Обсуждение. Таким образом, с учетом генеза аллергии и уровня поражения респираторного тракта, выявлены особенности микробного пейзажа слизистой оболочки носа. Так, для риносинуситов, установлена высокая концентрация семейства Enterobacteriaceae и снижение Staphylococcus hominis при ИАР относительно ПРС. При атопической бронхиальной астме выявлена повышенная концентрация микроорганизмов рода Enterococcus относительно аспириновой астмы.

В группах респираторной аллергией выявлено повышенное общее количество микробной флоры по сравнению с контролем. При атопии, независимо от уровня поражения респираторного тракта, обнаружено численное доминирование условно-патогенных микроорганизмов относительно псевдоатопии. Увеличение численности бактерий семейства Enterobacteriaceae и Enterococcus на слизистой характеризует дисбактериоз, акцентируя значимость этих семейств в инициации аллергической патологии верхних и нижних дыхательных путей. 


\section{Заключение}

При атопии (ИАР и АБА) установлен более выраженный дисбиоз. Отличием ИАР стало увеличение семейства Enterobacteriaceae и снижение Staphylococcus hominis относительно ПРС, а для нижних дыхательных путей - повышение Enterococcus при АБА относительно РАТ.

\section{Список литературы}

1. Игнатова И.А., Коленчукова О.А., Смирнова С.В., Манчук В.Т., Капустина Т.А., Кин Т.И., Чижмотря Н.М. Микробиоценоз слизистой оболочки носа при аллергической риносинусопатии // Журнал микробиологии, эпидемиологии и иммунобиологии. 2007. № 1. С. 62-63.

2. Коленчукова О.А., Смирнова С.В., Лазарева А.М. Особенности микробиоценоза слизистой оболочки носа при атопическом и полипозном риносинуситах // Журнал микробиологии, эпидемиологии и иммунобиологии. 2017. № 1. C. 67-73.

3. Лаптева А.М., Коленчукова О.А., Смирнова С.В. Особенности иммунного статуса и назального микробиоценоза при полипозном риносинусите и астматической триаде // Медицинская иммунология. 2016. Т. 18. № 6. С. 563-568.

\section{References}

1. Ignatova I.A., Kolenchukova O.A., Smirnova S.V., Manchuk V.T., Kapustina T.A., Kin T.I., Chizhmotrya N.M. Mikrobiocenoz slizistoi obolochki nosa pri allergicheskoi rinosinusopatii [Microbiocenosis of the nasal mucosa in allergic rhinosinusopathy]. Zhurnal mikrobiologii, epidemiologii i immunobiologii. 2007. № 1, pp. 62-63.

2. Kolenchukova O.A., Smirnova S.V., Lazareva A.M. Osobennosti mikrobiocenoza slizistoj obolochki nosa pri atopicheskom i polipoznom rinosinusitah [Features of microbiocenosis of the nasal mucosa in atopic and polypous rhinosinusitis]. Zhurnal mikrobiologii, epidemiologii i immunobiologii. 2017. № 1, pp. 67-73.

3. Lapteva A.M., Kolenchukova O.A., Smirnova S.V. Osobennosti immunnogo statusa i nazalnogo mikrobiocenoza pri polipoznom rinosinusite i astmaticheskoi triade [Features of the immune status and nasal microbiocenosis in polypous rhinosinusitis and asthmatic triad]. Medicinskaya immunologiya. 2016. V. 18. № 6, pp. 563-568.

\section{ДАННЫЕ ОБ АВТОРАХ}

Лазарева Анна Михайловна, очный аспирант

Научно-исследовательский институт медииинских проблем Севера - обособленного подразделения ФИЦ КНЦ СО РАН 
ул. Партизана Железняка, 3 Г., г. Красноярск, 660022, Российская Федераичия nuraaa@rambler.ru

Коленчукова Оксана Александровна, д.б.н., ведущий научный сотрудник лаборатории молекулярно-клеточной физиологии и патологии Научно-исследовательский институт медицинских проблем Севера - обособленного подразделения ФИЦ КНЦ СО РАН

ул. Партизана Железняка, 3 Г., г. Красноярск, 660022, Российская Федерация

Смирнова Светлана Витальевна, д.м.н., профессор, руководитель научного направления Научно-исследовательский институт медицинских проблем Севера - обособленного подразделения ФИЦ КНЦ СО РАН

ул. Партизана Железняка, 3 Г., г. Красноярск, 660022, Российская Федераичия

\section{DATA ABOUT THE AUTHORS}

Lazareva Anna Mickailovna, Post-graduate student

Research Institute of Medical Problems of the North - a separate division of the FIC KSC SB RAS

3 G, Partizana Zheleznyaka Str., Krasnoyarsk, 660022, Russian Federation nuraaa@rambler.ru

Kolenchukova Oksana Alexandrovna, $\mathrm{PhD}$, leading researcher of the laboratory of molecular cell physiology and pathology

Research Institute of Medical Problems of the North - a separate division of the FIC KSC SB RAS

3 G, Partizana Zheleznyaka Str., Krasnoyarsk, 660022, Russian Federation

Smirnova Svetlana Vitalievna, $\mathrm{PhD}$, Professor, Head of the Scientific Direction Research Institute of Medical Problems of the North - a separate division of the FIC KSC SB RAS

3 G, Partizana Zheleznyaka Str., Krasnoyarsk, 660022, Russian Federation 